\title{
Major, Minor and Toxic Minerals and Anti-Nutrients Composition in Edible Mushrooms Collected from Ethiopia
}

\author{
Woldegiorgis $A Z^{1 *}$, Abate $D^{2}$, Haki $\mathrm{GD}^{3}$ and Ziegler $\mathrm{GR}^{3}$
}

${ }^{1}$ Center for Food Science and Nutrition, P.O.BOX 1176 Addis Ababa University, Ethiopia

${ }^{2}$ Department of Life Sciences, P.O.BOX 1176, Addis Ababa University, Ethiopia

${ }^{3}$ Department of Food Science, The Pennsylvania State University, University Park, PA 16802, USA

\begin{abstract}
Major ( $\mathrm{Na}, \mathrm{K}, \mathrm{Ca}, \mathrm{Mg}, \mathrm{P})$, minor ( $\mathrm{Mn}, \mathrm{Cu}, \mathrm{Fe}, \mathrm{Zn}$ ) and toxic ( $\mathrm{Pb}, \mathrm{Cd}$ ) minerals composition of twelve edible mushrooms (Pleurotus ostreatus, Lentinula edodes, Agaricus bisporus \#1 (fresh), Agaricus bisporus \#2 (canned), Agaricus campestris, Laetiporus sulphureus, Termitomyces clypeatus, Termitomyces microcarpus \#1, Termitomyces microcarpus \#2, Termitomyces aurantiacus, Termitomyces letestui and Termitomyces species) collected from three regions of Ethiopia were analyzed. The samples were further investigated for their antinutrients (phytate and condensed tannin) to determine bioavailability of minerals. All the results are expressed in dry basis $(\mathrm{db})$. The major minerals concentration $(\mathrm{mg} / \mathrm{g}) \mathrm{ranged}$ : Na (0.41-34.8), $\mathrm{K}(3.66-42.4)$, $\mathrm{Ca}(0.29-6.45), \mathrm{Mg}$ (0.57-2.12) and $\mathrm{P}(0.71-2.82)$. The minor (mg/kg) ranged: Fe (32.5-6835.9), $\mathrm{Zn} \mathrm{(26.6-87.6),} \mathrm{Cu} \mathrm{(5.69-45.9)}$ and $\mathrm{Mn}$ (0.96-138.6). The toxic metal lead was detected (1.52-18.0 mg/kg), indicating most of the mushrooms samples exceeded the weekly tolerance limit set for $\mathrm{Pb}$ with more proportion in wild than cultivated mushrooms. Cadmium was detected only in A.campestris $(4.08 \mathrm{mg} / \mathrm{kg})$. The anti-nutrients $(\mathrm{mg} / 100 \mathrm{~g})$ were significantly varied with phytate ranged from 31.3 to 242.8 and condensed tannin from 4.81 to 31.7 . The calculated molar ratio between phytate and $\mathrm{Fe}, \mathrm{Zn}$ and Ca was above the suggested critical values indicating the bioavailability of $\mathrm{Fe}, \mathrm{Zn}$ and $\mathrm{Ca}$ to be high. In conclusion, the results imply that the edible mushrooms have high concentrations of essential minerals with lower anti-nutrients that make them bioavailable to the human body. Although, the consumption of some contaminated mushrooms should be avoided.
\end{abstract}

Keywords: Mushroom; Minerals; Major; Minor; Toxic; Antinutrients; Bioavailability

\section{Introduction}

The wide variety and abundance of minerals is the most valuable part of mushrooms as food which is related to species of mushroom, collecting area of the sample, age of fruiting bodies and mycelium, and distance from any source of pollution [1]. Potassium, phosphorous, copper, cobalt, aluminum and zinc are often present in mushrooms in high quantities. Some mushrooms tend to collect any minerals from their surroundings, even the toxic heavy metals such as lead, cadmium and mercury that are present in polluted areas [2].

It is also important to consider anti-nutritional factors that may be present in raw mushrooms. For example, it is known that A.bisporus and P.ostreatus contain hemaggluttinins that have shown to interfere with protein absorption in rats and have even produced lesions in the small intestine [3]. Moreover, mushrooms have been shown to contain some secondary plant products such as phytates, alkaloids, saponins, tannins and oxalate [4], which may decrease the bioavailability of the minerals. Bioavailability is a general term that refers to how well a nutrient can be absorbed and used by the body. It can be affected by many factors such as the presence of anti-nutrients, for example, phytates, oxalates, tannins and polyphenols in foods, a person's need, fibre, competition with other nutrients and acidity of intestinal environment [5].

Phytic acid, a compound found only in plant foods [6] is a phosphorus containing compound that binds with minerals and inhibits mineral absorption. The presence of phytate in foods has been associated with reduced mineral absorption due to the structure of phytate which has high density of negatively charged phosphate groups which form very stable complexes with mineral ions causing non-availability for intestinal absorption [7].

Condensed tannins (or proanthocyanidins, PAs) comprise a group of polyhydroxy-flavan-3-ol oligomers and polymers linked by carbon- carbon subunits [8]. The reactivity of PAs with molecules of biological significance had important nutritional and biological consequences. Their multiple phenolic hydroxyl groups lead to the formation of complexes with proteins [9-11] with metal ions [12-13] and with other macromolecules like polysaccharides [14].

There are many techniques used to determine the bioavailability of minerals in the human body. One of the methods is by measuring the molar ratio of phytate/minerals in the food and diet [15]. The proportion of samples with ratios above the suggested critical values have been calculated: [phytate]: [calcium] $>0.24$ [16], [phytate]: [iron] $>1$ [17], [phytate]: [zinc] $>15[15,18,19]$ [phytate] ${ }^{*}$ [calcium] $/[$ zinc] $>$ $0.5 \mathrm{~mol} / \mathrm{kg}[20,21]$.

Studies investigating the significance of the molar ratios of [Phy] $[\mathrm{Fe}],[\mathrm{Phy}]:[\mathrm{Zn}], \quad[\mathrm{Phy}]:[\mathrm{Ca}],[\mathrm{Phy}]{ }^{\star}[\mathrm{Ca}]:[\mathrm{Zn}]$ and proportion of the phytate phosphorus and non phytate phosphorus for determining of these minerals status obtained from edible mushrooms are not as exhaustive as studies done on cereals and legumes. Kalač [22] reported digestibility and bioavailability of mushroom constituents have been missing from the knowledge of mushroom nutritional value. Few authors such as Aletor [23], Ola et al., [24], Akindahunsi et al., [25] reported the concentration of antinutritional factors of some edible

*Corresonding author: Woldegiorgis AZ, Center for Food Science and Nutrition P.O.BOX 1176, Addis Ababa University, Ethiopia, Tel: +251 911194508; Fax: +251 111239470; E-mail: ashuyz1@yahoo.com

Received February 02, 2015; Accepted February 23, 2015; Published March 02, 2015

Citation: Woldegiorgis AZ, Abate D, Haki GD, Ziegler GR (2015) Major, Minor and Toxic Minerals and Anti-Nutrients Composition in Edible Mushrooms Collected from Ethiopia. J Food Process Technol 6: 430 doi:10.4172/2157-7110.1000430

Copyright: (c) 2015 Woldegiorgis AZ, et al. This is an open-access article distributed under the terms of the Creative Commons Attribution License, which permits unrestricted use, distribution, and reproduction in any medium, provided the original author and source are credited. 
mushrooms. In addition, no information is available about either the minerals or anti-nutrients composition of Ethiopian mushrooms.

Consequently, in this study the concentration of major minerals $(\mathrm{Na}, \mathrm{K}, \mathrm{Ca}, \mathrm{Mg}$, and $\mathrm{P})$, minor minerals $(\mathrm{Zn}, \mathrm{Fe}, \mathrm{Cu}$, and $\mathrm{Mn})$ and toxic minerals $(\mathrm{Pb}, \mathrm{Cd})$ and the antinutrients (phytate and condensed tannin) of edible mushrooms collected from Ethiopia were evaluated. Accordingly, the respective [Phy]: [Fe], [Phy]: $[\mathrm{Zn}],[\mathrm{Phy}]:[\mathrm{Ca}]$, $[\mathrm{Phy}]^{*}[\mathrm{Ca}]:[\mathrm{Zn}]$ molar ratios and the proportion of phytate phosphorus and non phytate phosphorus were calculated and compared to the critical values to predict the bioavailability of $\mathrm{Fe}, \mathrm{Zn}, \mathrm{Ca}$ and $\mathrm{P}$ obtained from these edible mushrooms to the human body.

\section{Materials and Methods \\ Description of sampling areas}

The three mushroom sampling areas were Addis Ababa, Kaffa zone and Benishangul Gumuz region of Ethiopia. Addis Ababa is the capital city of Ethiopia and located $9^{\circ} 01 \mathrm{~N}$ and $038^{\circ} 45 \mathrm{E}$. Kaffa zone is situated in the northwestern part of the southern nations, nationalities and people region state (SNNPR) and lies within $07^{\circ} 00^{\prime}-7^{\circ} 25^{\prime} \mathrm{N}$ latitude and $35^{\circ} 55^{\prime}-36^{\circ} 37^{\prime} E$ Longitude. Benishangul gumuz region is located in western parts of Ethiopia located between $09.17^{\circ}-12.06^{\circ}$ North latitude and $34.10^{\circ}-37.04^{\circ}$ East longitude.

\section{Sample collection and identification}

The collection of samples was based on their abundance and availability during the rainy season of the year (May-September). The samples were either collected from the field or purchased from the indigenous people who collect edible forest resources in the region or from the local markets. Identification of the wild edible mushrooms was made by making comparisons with authentic illustrations. Moreover, confirmations of the wild mushrooms were made by mycological experts at the department of life sciences at Addis Ababa University.

Within a two consecutive year a total of 12 edible mushrooms were collected where four of them were cultivated and eight of them were wild mushrooms. These are Pleurotus ostreatus, Lentinula edodes, Agaricus bisporus \#1 (fresh), Agaricus bisporus \#2 (canned), Agaricus campestris, Laetiporus sulphureus, Termitomyces clypeatus, Termitomyces microcarpus \#1, Termitomyces microcarpus \#2, Termitomyces aurantiacus, Termitomyces letestui and unidentified Termitomyces species. The first five mushrooms are collected from Addis Ababa, the next three are from Kaffa and the last four are from Benishangul Gumuz region, respectively.

\section{Preparation of samples and storage}

The mushroom samples were cleaned out of forest debris (without washing) with a plastic knife and sliced without separating the cap and the stipe of the mushrooms. Samples were dried in drying oven in the laboratory till constant weight. The dried samples were milled to fine powder (20 mesh) using a mill (FW 100, Yusung Industrial Ltd, China) and kept in plastic bottles until analysis.

\section{Determination of minerals (major, minor and toxic)}

Prevention of contamination: To minimize the risk of contamination, glass wares were washed with $10 \% \mathrm{HNO}_{3}$ acid and crucibles were soaked with $6 \mathrm{~N} \mathrm{HCl}$ for 24 hours after being washed with detergent and water. All materials were then rinsed with distilleddeionized water and dried in an oven before use.

Method detection limit and calibration curve: Estimation of the mineral concentration of the blank is important for the determination of the detection limit of the analytical method. Thus, eight reagent blanks were prepared in parallel and analyzed for their metal content as the samples. The pooled standard deviation of the eight blanks was calculated and multiplied by three to determine the method detection limit (MDL) of each metal [26]. Sample concentrations which are below the method detection limit $(\mu \mathrm{g} / \mathrm{g}$ ) were reported as not detected (nd). Calibration curve for each mineral was constructed using an appropriate standard at a series of concentrations. Regression equation for each metal standard was constructed and best fit of the equation was checked using correlation coefficient $\left(\mathrm{R}^{2}\right)$.

Digestion of mushroom samples: Digestion of mushroom samples was carried out by following the dry ashing method $[27,28]$ with some modifications. Two grams of sample was placed in a porcelain crucible and ashed in an oven at $450^{\circ} \mathrm{C}$ for $24 \mathrm{~h}$. Ashed material was dissolved in $2 \mathrm{ml}$ of concentrated $\mathrm{HNO}_{3}$, evaporated to dryness, heated again to $450^{\circ} \mathrm{C}$ for $4 \mathrm{~h}$. Samples then was dissolved in $2 \mathrm{ml}$ of concentrated $\mathrm{H}_{2} \mathrm{SO}_{4}, 2 \mathrm{ml}$ concentrated $\mathrm{HNO}_{3}$ and $2 \mathrm{ml}$ of $\mathrm{H}_{2} \mathrm{O}_{2}$, and diluted with distilled-deionized water up to $100 \mathrm{ml}$ after adding $1 \% \mathrm{LaCl}_{3}(2 \mathrm{ml})$ as releasing agent for $\mathrm{Ca}$ and $\mathrm{Mg}$ minerals. A blank digest was carried out in the same way.

Analysis of minerals with atomic absorption spectrometer: For the mineral analyses, PG-990 atomic absorption spectrometer (Beijing, China) was used by setting the appropriate wavelength for each metal. All metal ions (expect $\mathrm{K}, \mathrm{Na}$ and $\mathrm{P}$ ) determination was carried out in an air/acetylene flame mode of the spectrophotometer. $\mathrm{K}$ and $\mathrm{Na}$ levels in the mushroom samples were determined by CL 378 flame photometer (ELICO Limited, UK) using butane gas. Phosphorus was determined by UV-VIS spectrophotometer (Perkin Elmer, UK) using the molybdovanadate method [29].

Quality control: The reliability of the measurements was assessed by analyzing some of the minerals using the certified reference materials IRMM 804 (rice flour) and BCR-381 (Rye Flour) supplied by the Institute for Reference Materials and Measurements (IRMM, Geel, Belgium). For assessing the method performance, the measured values of a CRM were compared with the certified values. Moreover, a control sample was digested and analyzed with each analytical batch of samples to check the effectiveness of the digestion procedure. In order to further control the stability of the measurements, the last concentration of the standard solution was placed in a certain location of the auto-sampler loading list and it was analyzed every 10 samples.

\section{Antinutritional factors and bioavailability of minerals}

Phytate: The phytate content in the sample was determined according to the method described by Latta et al. [30] and later modified by Vaintraub et al., [31]. About $0.1 \mathrm{~g}$ of fresh samples was extracted with $10 \mathrm{ml} 2.4 \% \mathrm{HCl}$ in a mechanical shaker for 1 hour at a room temperature. The extract was centrifuged at $3000 \mathrm{rpm}$ for 30 minute. The clear supernatant was used for phytate estimation. One $\mathrm{ml}$ of wade reagent (containing $0.03 \%$ solution of $\mathrm{FeCl}_{3} \cdot 6 \mathrm{H}_{2} \mathrm{O}$ and $0.3 \%$ of sulfosalcilic acid in water) was added to $3 \mathrm{ml}$ of the sample solution (supernatant) and the mixture was mixed on a vortex for 5 seconds. Absorption readings at $500 \mathrm{~nm}$ were taken against a blank sample consisting of $3 \mathrm{ml}$ extract solution with $2 \mathrm{ml}$ of $2.4 \% \mathrm{HCl}$ without wade reagent. Sodium salt of phytic acid $(4.5-36 \mathrm{mg} / \mathrm{ml})$ was used as standard for construction of calibration curve (Absorbance $=-0.0064$ phytic acid $\left.\mathrm{mg}+0.3655, \mathrm{R}^{2}=0.9916\right)$.

Condensed tannin: Tannin was determined by Burns et al.,[32] 
as modified by Maxon ED [33]. One gram of sample was weighed and mixed with $10 \mathrm{ml} 1 \% \mathrm{HCl}$ in methanol in a screw cap test tube. Then the tube was shaken for $24 \mathrm{hr}$ at room temperature on a mechanical shaker. The solution was centrifuged at $1000 \mathrm{rpm}$ for 5 minutes. One $\mathrm{ml}$ of supernatant was transferred to another test tube and mixed with $5 \mathrm{ml}$ of vanillin- $\mathrm{HCl}$ reagent (prepared by combining equal volume of $8 \%$ concentrated $\mathrm{HCl}$ in methanol and $4 \%$ Vanillin in methanol). After 20 minutes, the absorbance of the solutions and the standard solution were measured at $500 \mathrm{~nm}$. Blank sample consisted $1 \mathrm{ml}$ of extract solution with $5 \mathrm{ml}$ of $1 \% \mathrm{HCl}$ without vanillin- $\mathrm{HCl}$ reagent. (+) catechin $(0.5-12 \mathrm{mg} / 100 \mathrm{ml})$ was used as standard for construction of calibration curve (Absorbance $=0.0054(+)$-catechin $\mathrm{mg}+0.0024$, $\left.\mathrm{R}^{2}=0.9971\right)$

Determination of molar ratio of phytate/mineral: The mole of phytate and minerals was determined by dividing the weight of phytate and minerals with its atomic weight (phytate: $660 \mathrm{~g} / \mathrm{mol}$; Fe: $56 \mathrm{~g} / \mathrm{mol}$; $\mathrm{Zn}: 65 \mathrm{~g} / \mathrm{mol}$; Ca: $40 \mathrm{~g} / \mathrm{mol}$ ). The molar ratio between phytate and mineral was obtained after dividing the mole of phytate with the mole of minerals [34]. Phytate phosphorous was calculated by assuming phytate contains $28 \%$ phosphorus, i.e. [Phytate $\mathrm{P}=$ phytate ${ }^{\star} 0.28$ ] and accordingly non phytate phosphorous=total phosphorous-phytate phosphorous.

\section{Statistical analysis}

Completely randomized design (CRD) was used. All the experimental results were reported as mean \pm standard error (SE) of three parallel measurements. Data were evaluated by using one way variance analysis (ANOVA) and means were separated by Duncan multiple range test (DMRT).A linear regression correlations test $\left(\mathrm{R}^{2}\right)$ was performed to investigate correlations between metal concentrations. SPSS version 15.0 was used for determining of significance at $\mathrm{p}<0.05$.

\section{Results and Discussion}

\section{Method detection limits and quality assurance}

The method detection limits, wavelengths at which analysis was done and the correlation coefficients of the calibration curve for each of the metals. The results clearly show that method detection limits and the calibration curves were in good range for the analysis of metals in the mushroom samples. Moreover, the measured values of the certified reference materials are somewhat in good agreement with the certified values.

\section{Major minerals}

As shown in Table 1 the concentration of the major minerals in dry basis $(\mathrm{Na}, \mathrm{K}, \mathrm{Ca}, \mathrm{Mg}$ and $\mathrm{P})$ is expressed in $\mathrm{mg} / \mathrm{g}$. The sodium content ranged from $0.41 \mathrm{mg} / \mathrm{g}$ (T.letestui) to $34.8 \mathrm{mg} / \mathrm{g}$ (A.bisporus\#2). The higher amount of sodium in A.bisporus\#2 is due to the incorporation of salt in addition to citric acid and water during canning of whole or sliced button mushrooms. The sodium concentration in mushroom from other report ranges from $0.03-4.85 \mathrm{mg} / \mathrm{g}$ [35]. Thus, excluding the canned mushroom (i.e. A.bisporus \#2), the sodium content of Ethiopian mushrooms were in the range of 0.41 to $1.83 \mathrm{mg} / \mathrm{g}$ which is in good agreement with the literature. The concentration of sodium is relatively low (except canned mushroom) and this is of very great nutritional benefit to the consumer, a finding that has been corroborated by Vetter [36]. Potassium content was higher than other minerals in all mushrooms in this study, varying between $3.66 \mathrm{mg} / \mathrm{g}$ (L.sulphureus) and $42.4 \mathrm{mg} / \mathrm{g}$ (T.clypeatus). Potassium concentration in mushrooms from other report ranges from 12.6 to $29.1 \mathrm{mg} / \mathrm{g}$ dry basis. The low concentration of sodium and the presence of a great amount of potassium suggest the utilization of mushrooms in an antihypertensive diet (Table 1).

Calcium content ranged from $0.29 \mathrm{mg} / \mathrm{g}$ (T.sp) to to $6.45 \mathrm{mg} / \mathrm{g}$ (T.aurantiacus) indicating these mushrooms could be a good source of calcium. Calcium content in mushrooms from other report ranges from 0.17 to $8.80 \mathrm{mg} / \mathrm{g} \mathrm{dw}$ [35]. Magnesium varied from $0.57 \mathrm{mg} / \mathrm{g}$ (L.sulphureus) to $2.12 \mathrm{mg} / \mathrm{g}$ (P.ostreatus) again indicating these mushrooms could be a good source of minerals. Magnesium content in mushrooms from other report ranges from 0.90 to $4.54 \mathrm{mg} / \mathrm{g} \mathrm{dw}$ [35]. Phosphorus varied from $0.71 \mathrm{mg} / \mathrm{g}$ (A.bisporus\#2) to $2.82 \mathrm{mg} / \mathrm{g}$ (A.bisporus\#1). Phosphorus content in mushrooms from other report ranges from 0.64 to $4.49 \mathrm{mg} / \mathrm{g} \mathrm{dw}$ [35]. As compared with vegetables, mushrooms proved to be good sources of various minerals with $\mathrm{K}$ and $\mathrm{P}$ being the main constituents of mushrooms ash [37].

\section{Minor (trace) minerals}

Trace minerals are of great biochemical interest and exhibit nutritional and clinical importance [38]. The concentrations of trace minerals in dry basis ( $\mathrm{Fe}, \mathrm{Zn}, \mathrm{Cu}$, and $\mathrm{Mn}$ ) in the edible mushroom species based on dry weight as $\mathrm{mg} / \mathrm{kg}$ were shown in Table 2 . The lowest iron content was $32.5 \mathrm{mg} / \mathrm{kg}$ for A.bisporus\#2 and the highest iron content was observed by T.microcarpus\#1 with $6835.9 \mathrm{mg} / \mathrm{kg}$. Iron concentration of mushrooms was reported in the ranges of 180 to 407 $\mathrm{mg} / \mathrm{kg}$ [39], 7.5 to $142 \mathrm{mg} / \mathrm{kg}$ [40], 50.1-842 mg/kg [35], 31.3-1190 $\mu \mathrm{g} / \mathrm{g}$ [41], 568-3904 $\mu \mathrm{g} / \mathrm{g}$ [42], 56.1-7162 $\mu \mathrm{g} / \mathrm{g}$ [43]. 102-1580 $\mu \mathrm{g} / \mathrm{g}$ [44] 30-

\begin{tabular}{|c|c|c|c|c|c|c|}
\hline No. & Mushroom Type & $\mathrm{Na}$ & $\mathbf{K}$ & $\mathrm{Ca}$ & Mg & $\mathbf{P}$ \\
\hline 1 & P.ostreatus & $0.83 \pm 0.17 c, d, e$ & $20.6 \pm 0.15 c, d$ & $1.16 \pm 0.06 d$ & $2.12 \pm 0.02 a$ & $2.50 \pm 0.03 b, c$ \\
\hline 2 & L.edodes & $0.99 \pm 0.00 \mathrm{c}, \mathrm{d}, \mathrm{e}$ & $14.3 \pm 0.17 e$ & $2.07 \pm 0.12 b, c$ & $1.65 \pm 0.05 c$ & $1.16 \pm 0.02 f$ \\
\hline 3 & A.bisporus\#1 & $0.77 \pm 0.02 d, e, f$ & $23.7 \pm 0.11 \mathrm{c}$ & $2.24 \pm 0.26 b$ & $1.92 \pm 0.03 b$ & $2.82 \pm 0.03 a$ \\
\hline 4 & A. bisporus\#2 & $34.8 \pm 0.12 a$ & $6.46 \pm 0.02 f$ & $1.69 \pm 0.24 c$ & $0.90 \pm 0.04 f$ & $0.71 \pm 0.03 g$ \\
\hline 5 & A.campestris & $1.17 \pm 0.17 c, d$ & $17.3 \pm 0.60 \mathrm{~d}, \mathrm{e}$ & $0.91 \pm 0.08 d, e$ & $1.57 \pm 0.04 c$ & $2.14 \pm 0.11 d, e$ \\
\hline 6 & L.sulphureus & $0.67 \pm 0.17 e, f$ & $3.66 \pm 0.16 f$ & $0.80 \pm 0.08 d, e$ & $0.57 \pm 0.00 \mathrm{~h}$ & $1.34 \pm 0.04 f$ \\
\hline 7 & T.clypeatus & $1.83 \pm 0.44 b$ & $42.4 \pm 0.28 a$ & $0.94 \pm 0.08 \mathrm{~d}, \mathrm{e}$ & $2.00 \pm 0.01 a, b$ & $2.65 \pm 0.03 a, b$ \\
\hline 8 & T.microcarpus\#1 & $1.75 \pm 0.14 b$ & $32.6 \pm 3.42 b$ & $0.83 \pm 0.18 \mathrm{~d}, \mathrm{e}$ & $1.10 \pm 0.11 \mathrm{e}$ & $2.16 \pm 0.21 c$ \\
\hline 9 & T.aurantiacus & $0.49 \pm 0.00 e, f$ & $22.1 \pm 1.30 c$ & $6.45 \pm 0.20 a$ & $1.30 \pm 0.08 d$ & $1.36 \pm 0.07 f$ \\
\hline 10 & T. microcarpus \#2 & $1.33 \pm 0.29 b, c$ & $29.5 \pm 2.07 b$ & $0.89 \pm 0.09 \mathrm{~d}, \mathrm{e}$ & $1.06 \pm 0.06 \mathrm{e}$ & $1.98 \pm 0.11 \mathrm{e}$ \\
\hline 11 & T.letestui & $0.41 \pm 0.04 f$ & $22.8 \pm 1.64 c$ & $0.55 \pm 0.09 e, f$ & $0.73 \pm 0.04 \mathrm{~g}$ & $2.08 \pm 0.06 e$ \\
\hline 12 & T. sp & $0.43 \pm 0.01 f$ & $24.4 \pm 0.01 c$ & $0.29 \pm 0.01 f$ & $0.88 \pm 0.03 f, g$ & $2.36 \pm 0.05 c, d$ \\
\hline
\end{tabular}

- Means followed by same letter in the same column are not significantly different $(p>0.05$

- Data are mean \pm standard error of three parallel measurements $(n=3)$

Table 1: Major minerals content $(\mathrm{mg} / \mathrm{g})$ of cultivated and wild edible mushrooms collected from Ethiopia in dry basis. 


\begin{tabular}{|c|l|c|c|c|c|}
\hline No. & Mushroom Type & Fe & Zn & Mn \\
\hline 1 & P.ostreatus & $72.7 \pm 3.49 \mathrm{e}$ & $61.8 \pm 1.16 \mathrm{~d}$ & $11.1 \pm 0.58 \mathrm{~g}, \mathrm{~h}$ \\
\hline 2 & L.edodes & $98.0 \pm 1.29 \mathrm{e}$ & $80.9 \pm 0.94 \mathrm{~b}$ & $12.2 \pm 0.73 \mathrm{~g}$ \\
\hline 3 & A.bisporus\#1 & $63.2 \pm 0.05 \mathrm{e}$ & $81.5 \pm 0.28 \mathrm{~b}$ & $39.0 \pm 0.46 \mathrm{~b}$ \\
\hline 4 & A. bisporus\#2 & $32.5 \pm 0.92 \mathrm{e}$ & $26.6 \pm 1.74 \mathrm{~g}$ & $8.59 \pm 0.29 \mathrm{~h}$ \\
\hline 5 & A.campestris & $1679.5 \pm 23.94 \mathrm{c}$ & $87.6 \pm 0.89 \mathrm{a}$ & $33.6 \pm 0.96 \mathrm{c}$ \\
\hline 7 & L.sulphureus & $168.9 \pm 11.1 \mathrm{e}$ & $38.8 \pm 1.06 \mathrm{f}$ & $1.46 \pm 0.36 \mathrm{f}$ \\
\hline 8 & T.microcarpus\#1 & $406.8 \pm 7.70 \mathrm{~d}, \mathrm{e}$ & $76.9 \pm 0.54 \mathrm{c}$ & $5.69 \pm 0.77 \mathrm{i}$ \\
\hline 10 & T.aurantiacus & $6835.9 \pm 1925 \mathrm{a}$ & $61.3 \pm 8.06 \mathrm{~d}$ & $45.9 \pm 0.43 \mathrm{a}$ \\
\hline 11 & T.letestui & $1378.4 \pm 114 \mathrm{c}, \mathrm{d}$ & $44.0 \pm 1.69 \mathrm{e}$ & $10.9 \pm 1.78 \mathrm{~g}, \mathrm{~h}$ \\
\hline 12 & T. sp & $3192.4 \pm 336.8 \mathrm{~b}$ & $84.4 \pm 4.83 \mathrm{a}, \mathrm{b}$ & $14.8 \pm 0.82 \mathrm{f}$ \\
\hline
\end{tabular}

- Means followed by same letter in the same column are not significantly different $(p>0.05)$

- Data are mean \pm standard error of three parallel measurements $(n=3)$

Table 2: Minor minerals content $(\mathrm{mg} / \mathrm{kg}$ ) of cultivated and wild edible mushrooms collected from Ethiopia in dry basis.

$150 \mu \mathrm{g} / \mathrm{g}$ [2], respectively. Thus, as compared to other studies, the iron content of Ethiopian mushrooms was in agreement with some of the reported values in the literature. It is known that adequate iron in a diet is very important in order to decrease the incidence of anemia (Table 2).

As indicated in Table 2, the zinc content was the lowest $(26.6 \mathrm{mg} /$ $\mathrm{kg}$ ) in A.bisporus \#2, whereas the highest $(87.6 \mathrm{mg} / \mathrm{kg}$ ) in A.campestris. Mushrooms are known as zinc accumulators and the sporophore: substrate ratio for $\mathrm{Zn}$ ranges from 1 to $10 \mathrm{mg} / \mathrm{kg}$ [43] Zinc is widespread among living organisms, due to its biological significance. A zinc concentration of mushrooms was reported in the ranges of $30-150 \mu \mathrm{g} / \mathrm{g}$ [2], 33.5- $89.5 \mu \mathrm{g} / \mathrm{g}$ [44] and 29.3-158 $\mu \mathrm{g} / \mathrm{g}$ [43]. Hence, zinc content in mushrooms of the present study is in agreement with previous studies $[2,28]$.

The minimum and maximum values of copper were 5.69 and 45.9 $\mathrm{mg} / \mathrm{kg}$ in L.sulphureus and T.clypeatus, respectively. Copper content of mushroom samples in other reports ranged from 4.71-51.0 $\mu \mathrm{g} / \mathrm{g}$ [45] and 10.3-145 $\mu \mathrm{g} / \mathrm{g}$ [41]. Similar to the reports copper content of Ethiopian mushroom species are within range and can be a good source of copper. The values, such as $45.9 \mathrm{mg} / \mathrm{kg}$ for T.clypeatus, 39.0 $\mathrm{mg} / \mathrm{kg}$ for $A$. bisporus $\# 1$ and $33.6 \mathrm{mg} / \mathrm{kg}$ for A.campestris are high. This indicates consuming $30 \mathrm{~g}$ of dry matter of these three mushrooms a person can meet the recommended dietary allowance (RDA) of $900 \mu \mathrm{g} /$ day set by EU $[2,46]$ reported that $\mathrm{Cu}$ levels in the accumulating species are usually $100-300 \mathrm{mg} / \mathrm{kg}$ dry matter, which is not considered a health risk. Copper content in mushrooms is higher than those in vegetables should be considered as a nutritional source of the element [35].

The manganese content of the mushrooms ranged from $0.96 \mathrm{mg} /$ $\mathrm{kg}$ (L.sulphureus) to $138.6 \mathrm{mg} / \mathrm{kg}$ (T.microcarpus\#1). The values of manganese in the literatures for mushrooms were $14.2-69.7 \mu \mathrm{g} / \mathrm{g}, 21.7-$ $74.3 \mu \mathrm{g} / \mathrm{g}, 7.1-81.3 \mathrm{ug} / \mathrm{g}$ and $5.54-135 \mathrm{mg} / \mathrm{kg}$ respectively [28,35,44,47]. The manganese values in this study are in agreement with results in the literature.

One important observation in this study was the only wood inhabiting polypores (L.sulphureus) evaluated in this study had the least mineral $(\mathrm{Ca}, \mathrm{Mn}, \mathrm{Cu}, \mathrm{Mg}, \mathrm{K})$ concentration [48] reported that the members of the Polyporaceae (polypores) had relatively low mineral contents, and the percentage of copper, zinc, manganese and lead was lower in mushrooms that grew on wood than on the ground.

\section{Toxic minerals}

Many wild edible mushroom species are known to accumulate high levels of heavy (toxic) metals and mainly cadmium, mercury

\begin{tabular}{|c|l|c|c|}
\hline No. & Mushroom Type & Cd & Pb \\
\hline 1 & P.ostreatus & nd $(<0.028)$ & $5.45 \pm 1.09 \mathrm{c}$ \\
\hline 2 & L.edodes & nd $(<0.028)$ & $1.52 \pm 0.73 \mathrm{~d}$ \\
\hline 3 & A.bisporus\#1 & nd $(<0.028)$ & $18.0 \pm 0.11 \mathrm{a}$ \\
\hline 4 & A. bisporus\#2 & nd $(<0.028)$ & $11.7 \pm 0.73 \mathrm{~b}$ \\
\hline 5 & A.campestris & $4.08 \pm 0.38 \mathrm{a}$ & $8.68 \pm 1.95 \mathrm{~b}$ \\
\hline 6 & L.sulphureus & $\mathrm{nd}(<0.028)$ & $3.40 \pm 0.88 \mathrm{c}, \mathrm{d}$ \\
\hline 7 & T.clypeatus & $\mathrm{nd}(<0.028)$ & $10.1 \pm 1.19 \mathrm{~b}$ \\
\hline 8 & T.microcarpus\#1 & $\mathrm{nd}(<0.028)$ & $4.03 \pm 0.30 \mathrm{c}, \mathrm{d}$ \\
\hline 9 & T.aurantiacus & $\mathrm{nd}(<0.028)$ & $9.84 \pm 1.66 \mathrm{~b}$ \\
\hline 10 & T. microcarpus \#2 & $\mathrm{nd}(<0.028)$ & $12.3 \pm 0.32 \mathrm{~b}$ \\
\hline 11 & T.letestui & $\mathrm{nd}(<0.028)$ & $17.2 \pm 1.51 \mathrm{a}$ \\
\hline 12 & T. sp $\mathrm{nd}(<0.028)$ & $11.9 \pm 1.72 \mathrm{~b}$ \\
\hline
\end{tabular}

- Means followed by same letter in the same column are not significantly different $(p>0.05)$

- Data are mean \pm standard error of three parallel measurements $(n=3)$

Table 3: Toxic minerals content $(\mathrm{mg} / \mathrm{kg})$ of cultivated and wild edible mushrooms collected from Ethiopia in dry basis.

and lead [2], perhaps related to the environment in which they are picked [49]. The two toxic metals cadmium and lead were evaluated here for Ethiopian mushrooms. Cadmium was detected only in one of the sample (A.campestris) at a concentration of $4.08 \mathrm{mg} / \mathrm{kg}$ in dry basis (Table 3 ), while the others are below the MDL $(<0.03 \mu \mathrm{g} / \mathrm{g})$. This exceptionality of A.campestris might be due to the proximity of the samples to roads [50] reported high metals levels $(\mathrm{Pb}, \mathrm{Cd}, \mathrm{Hg}, \mathrm{Cu})$ in mushrooms growing in heavily contaminated areas, such as those in the vicinity of highways with heavy traffic. The level of $\mathrm{Cd}$ from other report ranges from 0.3 to $3.0 \mu \mathrm{g} / \mathrm{g}$ [28] and 0.4 to $91.8 \mathrm{mg} / \mathrm{kg}$ [27] The Cd levels of Ethiopian mushrooms are in agreement with literature values. Cadmium is accumulated mainly in kidneys, spleen and liver and its level in blood serum increases considerably following mushroom consumption [2] Thus, the consumption of contaminated mushrooms such as A.campestris may pose a health risk for consumers, especially during the rainy season when intake is high (Table 3 ).

Lead was detected in all of the samples ranging from $1.52 \mathrm{mg} /$ $\mathrm{kg}$ (L.edodes) to as high as $18.0 \mathrm{mg} / \mathrm{kg}$ (A.bisporus\#1). The $\mathrm{Pb}$ concentrations in other studies were between 0.1 and $40 \mathrm{mg} / \mathrm{kg}[40,51]$. Higher concentration of $\mathrm{Pb}$ in Agaricus species is also found by Chen et al., [27]. The uptake of heavy metal ions in mushrooms is higher than in plants. For this reason, the concentration variations of heavy metals could be attributed to mushroom species and their ecosystems. However, no mushroom species can be considered as an exact indicator of environmental pollution [2]. Certain countries have established 
statutory limits for metals in edible mushrooms. In the Czech Republic, limits of 2.0 and $10.0 \mathrm{mg} / \mathrm{kg}$ dry matter have been established for $\mathrm{Cd}$ and $\mathrm{Pb}$, respectively, in wild-growing mushrooms; whereas 1.0 and $10 \mathrm{mg} / \mathrm{kg}$ dry matter have been established for cultivated mushrooms [2]. In Poland, recommendations concerning the concentrations of $\mathrm{Cd}$ and $\mathrm{Pb}$ in dried mushrooms are slightly different. Tolerance limits set for $\mathrm{Cd}$ and $\mathrm{Pb}$ are 1.0 and $2.0 \mathrm{mg} / \mathrm{kg}$ dry weight, respectively [40]. The maximum level for certain contaminants in foodstuffs established by the Commission of the European Communities (Commission Regulation [EC] No 466/2001) is set at about 0.2 and $0.3 \mathrm{mg} / \mathrm{kg}$ wet weight for $\mathrm{Cd}$ and $\mathrm{Pb}$, respectively, in cultivated fungi. Assuming that the dry matter content of mushrooms is $10 \%$ [2], these same limits for dry material will be ten times higher and approach 2.0 and $3.0 \mathrm{mg} / \mathrm{kg}$ dry weight for $\mathrm{Cd}$ and $\mathrm{Pb}$, respectively. Thus, in Ethiopian mushrooms as shown in Table 3, the concentration of Cd for A.campestris (4.08 $\mathrm{mg} / \mathrm{kg}$ ) only exceeded the tolerance limits set by Czech, Poland and EU for dried mushrooms. In the contrary, the lead content in most of the fruiting bodies of mushroom analyzed was higher than the statutory limits set by EU and Poland except for L.edodes $(1.57 \mathrm{mg} / \mathrm{kg}$ ) which is safe.

\section{Metal-to-Metal correlation}

A linear regression correlations test was performed to investigate correlations between metal concentrations. The values of correlation coefficients between metal concentrations. There are good correlations between sodium and potassium $(r=-0.41)$, sodium and phosphorus $(r=-$ $0.57)$, potassium and magnesium $(\mathrm{r}=0.41)$, potassium and phosphorus $(\mathrm{r}=0.71)$, potassium and zinc $(\mathrm{r}=-0.340$, potassium and iron $(\mathrm{r}=0.42)$, potassium and manganese $(r=0.39)$, potassium and copper $(r=0.53)$, magnesium and phosphorus $(\mathrm{r}=0.51)$, magnesium and iron $(\mathrm{r}=0.34)$, magnesium and copper $(\mathrm{r}=0.54)$, phosphorus and copper $(\mathrm{r}=0.67)$, phosphorus and lead $(\mathrm{r}=0.34)$, zinc and cadmium $(\mathrm{r}=0.38)$, iron and manganese $(r=0.87)$, copper and cadmium $(r=0.33)$ and copper and lead $(r=0.45)$. From these good correlations, except the negative correlations between sodium and potassium, sodium and phosphorus and potassium and zinc all other the correlations are positive. The other correlations between metals were not significant. Similar correlations between some of metals of mushroom were also reported by Chen et al. and Mendil et al., [27,39].

\section{Daily mineral intakes and toxicity}

According to the EU scientific committee for food adult weight parameter, $60 \mathrm{~kg}$ of body weight was used for intake calculations as the weight of an average consumer. In addition, for intake calculations, usually a $300 \mathrm{~g}$ portion of fresh mushrooms per meal is assumed, which contains $30 \mathrm{~g}$ of dry matter [2].

The significance to human health of the element concentrations found in fruiting bodies of edible fungi may also be assessed by comparing estimated exposures with exposures from a normal diet and with the internationally agreed exposure guidelines, where these exist [40]. These guidelines are the Provisional Tolerable Weekly Intakes (PTWIs) or Provisional Maximum Tolerable Daily Intakes (PMTDIs) set by the Joint Expert Committee on Food Additives (JECFA) FAO/ WHO [52] or by EU Scientific Committee [53]. Acceptable weekly intakes of $\mathrm{Cd}$ and $\mathrm{Pb}$ for adults are $0.42-0.49$ and $1.5-1.75 \mathrm{mg}$, respectively. These values correspond to 0.06 and $0.21 \mathrm{mg}$ of $\mathrm{Cd}$ and $\mathrm{Pb}$, respectively, on a daily basis.

Thus, in relation to the above $\mathrm{FAO} / \mathrm{WHO}$ or $\mathrm{EU}$ guidelines, the PTWI for Cd assuming $60 \mathrm{~kg}$ body weight is $0.84 \mathrm{mg} /$ week for
A.campestris which is almost 2 fold of the weekly tolerance limit. Similarly, the PTWI for $\mathrm{Pb}$ for the analysed mushrooms: P.ostreatus (1.12 mg/week), L.edodes (0.35 mg/week), L.sulphureus (0.7 mg/week), A.campestris (1.82 mg/week), T.clypeatus ( $2.1 \mathrm{mg} /$ week), T.microcarpus \#1 $(0.84 \mathrm{mg} / \mathrm{week})$, T.aurantiacus $(2.03 \mathrm{mg} /$ week), T.microcarpus\#2 ( $2.59 \mathrm{mg} /$ week), A.bisporus \#1 (3.78 mg/week) and A.bisporus \#2 (2.45 $\mathrm{mg} /$ week) indicating most of the mushrooms samples exceeded the weekly tolerance limit set for $\mathrm{Pb}$ with more proportion in wild than cultivated mushrooms

\section{Anti-nutritional factors}

Table 4 presents the antinutrients (phytate and tannin) distribution of the most commonly consumed cultivated and wild edible mushrooms collected from Ethiopia (Table 4).

Phytates: The phytate content varied from $31.3 \mathrm{mg} / 100 \mathrm{~g}$ for A.bisporus\#1 to $242.8 \mathrm{mg} / 100 \mathrm{~g}$ for A.bisporus\#2 in dry basis. From other reports the phytate concentration of cap, stalk and tuber of mushroom analyzed separately were in the ranges of 282 to $958 \mathrm{mg} / 100$ $\mathrm{g}$ [24] and 338 to $1815 \mathrm{mg} / 100 \mathrm{~g}[23,25]$. Aletor reported that phytic acid in tropical species ranged from 100 to $360 \mathrm{mg} / 100 \mathrm{~g}$ where samples were analyzed as a whole (without separating the cap and pileus). This report was in line with our report as the analysis of Ethiopian mushrooms was also carried as a whole. According to Akindahunsi et al. [54] the phytate content of mushrooms was low when compared to green leafy vegetable whose phytate content was exceptionally high. Phytic acid forms very stable complexes with mineral ions rendering them unavailable for intestinal uptake because the first step in mineral absorption requires that the mineral remain in the ionic state [7] thus inducing mineral deficiencies. Since the level of phytic acid is low in the analyzed samples, mushrooms could be another possible option to combat mineral deficiencies in Ethiopia.

Sandberg et al. [55] suggested that food processing such as cooking, fermentation, autoclaving and milling can reduce or eliminate the level of phytic acid by altering the inositol hexaphosphate to other degradation forms, e.g. penta-, tetra-, tri-, di- and monophosphate. However, forms such as IP1, IP2 and IP3 have less capacity to bind metal ions, or the complex formed is more soluble, which may reduce the negative effect on mineral absorption [56,57]. Similar reduction in phytic acid was observed in one of our canned mushroom (A.bisporus \#2) having the least phytic acid content of $31.3 \mathrm{mg} / 100 \mathrm{~g}$. This reduction might be due to the leaching out of phytate to the water which was used to soak whole or sliced mushroom samples. A further investigation is needed to exactly evaluate the effect of heat, preservative (salt and

\begin{tabular}{|r|l|c|c|}
\hline No. & Mushroom Type & Phytate & Tannin \\
\hline 1 & P.ostreatus & $155.8 \pm 12.1$ & $4.81 \pm 1.35$ \\
\hline 2 & L.edodes & $104.4 \pm 2.02$ & $10.6 \pm 0.46$ \\
\hline 3 & A.bisporus\#1 & $242.8 \pm 54.9$ & $31.7 \pm 1.39$ \\
\hline 4 & A. bisporus\#2 & $31.3 \pm 6.03$ & $10.0 \pm 1.26$ \\
\hline 5 & A.campestris & $235.3 \pm 25.4$ & $22.5 \pm 0.99$ \\
\hline 6 & L.sulphureus & $147.6 \pm 3.32$ & $8.72 \pm 0.83$ \\
\hline 7 & T.clypeatus & $106.5 \pm 12.5$ & $16.9 \pm 0.97$ \\
\hline 8 & T.microcarpus\#1 & $119.8 \pm 8.88$ & $16.7 \pm 1.12$ \\
\hline 9 & T.aurantiacus & $\mathrm{NA}$ & $\mathrm{NA}$ \\
\hline 10 & T. microcarpus\#2 & $186.8 \pm 28.9$ & $26.1 \pm 3.25$ \\
\hline 11 & T.letestui & $98.2 \pm 1.44$ & $20.1 \pm 0.69$ \\
\hline 12 & T.sp & $70.1 \pm 1.33$ & $32.5 \pm 0.55$ \\
\hline
\end{tabular}

${ }^{*} \mathrm{NA}=$ not analyzed

Table 4: Antinutrients content $(\mathrm{mg} / 100 \mathrm{~g})$ of cultivated and wild edible mushrooms collected from Ethiopia in dry basis. 
citric acid) and water used in canning of mushroom to the reduction of antinutrients such as phytate and tannin.

Condensed tannins: Tannins are known to retard growth through reduced digestion and/or absorption [58]. Condensed tannin content expressed as $(+)$ - catechin equivalent was varied from $4.81 \mathrm{mg} / 100 \mathrm{~g}$ (0.05\%) for P.ostreatus to $32.5 \mathrm{mg} / 100 \mathrm{~g}(0.32 \%)$ for T.sp. From other reports the concentration of condensed tannin of the cap, stalk and tuber of mushroom where analyzed separately were in the ranges of $0.1 \%(10 \mathrm{mg} / 100 \mathrm{~g})$ to $1.1 \%(110 \mathrm{mg} / 100 \mathrm{~g})$ [24] and $0.21 \%(21 \mathrm{mg} / 100$ g) to $0.31 \%(31 \mathrm{mg} / 100 \mathrm{~g})$ [25]. Akindahunsi et al.[25] and Aletor [23] reported that tannin concentrations (\%TA) in mushrooms were low. These levels might not affect the nutritional potentials of the mushroom parts since they were all less than $10 \%$ of the total dry weight of the samples [59].

Molar ratios and bioavailability of minerals: The molar ratio of phytate/mineral of all mushroom samples analyzed are summarized and shown in Table 5. The molar ratios of [phy]: [Zn] of all mushrooms samples were $<10$ indicating a good zinc bioavailability. Similarly the molar ratio of [phy]: [Ca] of $<0.24$ indicating good calcium bioavailability also. Moreover calcium promotes zinc bioavailability in all the samples since molar ratio of [Phytate $]^{*}[\mathrm{Ca}]$ : [Zn] were $<0.5 \mathrm{~mol} /$ $\mathrm{kg}$. For iron content, all mushroom samples had good bioavailability except A.bisporus\# 1 and P.ostreatus with [Phytate]: [Fe] molar ratio $>1$ (Table 5).

\section{Phy: Zn}

The importance of a foodstuff as a source of dietary zinc depends on both the total zinc content and the level of other constituents in the diet that affect zinc bioavailability. Phytate may reduce the bioavailability of dietary zinc by forming insoluble mineral chelates at a physiological $\mathrm{pH}[60]$. The formation of the chelates depends on relative levels of both zinc and phytic acid [61]. Hence, the phytate: $\mathrm{Zn}$ molar ratio is considered a better indicator of zinc bioavailability than total dietary phytate levels alone[62]. Oberleas et al., showed that foods with a molar ratio of Phy: $\mathrm{Zn}$ less than 10 showed adequate availability of $\mathrm{Zn}$ and problems were encountered when the value was greater than 15 . In Table 5, the Phy: Zn molar ratios are shown for the cultivated and wild edible mushrooms analysed. All the mushroom samples analyzed had low Phy: $\mathrm{Zn}$ values which is less than the critical value 15 . This means that $\mathrm{Zn}$ obtained from these mushrooms would be bioavailable for the human body.

\section{Phy: Fe}

Phytate is known to be the main inhibitor of iron absorption in plant-based diets. To cancel out the adverse effect of phytates on iron absorption, phytate contents have to be reduced to concentrations of less than $0.1 \mathrm{~g} / 100 \mathrm{~g}$. In cereal-based dishes, it has been shown that the phytate/iron molar ratio has to be lower than 1 , and preferably 0.4 , to obtain a significant increase in absorption [63]. With this regard, most of our mushroom samples had phy: Fe molar ratios lower than 1 with the exception of A.bisporus\# 1 and P.ostreatus (Table 5). This indicates iron from these mushroom would be bioavailable to the human body.

\section{Phy: Ca}

Phytic acids markedly decrease Ca bioavailability and the Phy: Ca molar ratio has been proposed as an indicator of $\mathrm{Ca}$ bioavailability. The critical molar ratio of Phy: $\mathrm{Ca}$ is reported to be 0.24 [16]. The molar ratios of Phy: Ca obtained for both cultivated and wild edible mushrooms of Ethiopia (Table 5) were all less than the critical value indicating that absorption of calcium won't be adversely affected by phytate in these mushroom species.

\section{PhyCa: Zn}

A kinetic synergism exists between $[\mathrm{Ca}]$ and $[\mathrm{Zn}]$ ion resulting in a Ca: $\mathrm{Zn}$ : phytate complex, which is less soluble than phytate complex formed by either ion alone [60]. Table 5 presented the values for the molar ratios of [Ca] [Phy]/ [Zn] i.e. (Ca x Phy:Zn) [21]. Ellis et al. and [20] Davies et al. indicated that the ratio of $\mathrm{Ca} \times \mathrm{Phy}: \mathrm{Zn}$ is a better predictor of $\mathrm{Zn}$ availability and said that, if the value were greater than $0.50 \mathrm{~mol} / \mathrm{kg}$, there would be interferences with the availability of $\mathrm{Zn}$. In our results, the calculated Cax Phy: $\mathrm{Zn}$ values were all lower than 0.50 $\mathrm{mol} / \mathrm{kg}$ for the edible mushrooms analyzed. This means, $\mathrm{Zn}$ availability would not be affected by the presence of calcium. This bioavailability of zinc might be related to the level of phytate present in the samples were not high enough to adversely affect it. Similar bioavailability of $\mathrm{Zn}$ in all mushroom samples was revealed by [24]. Ola et al. and reported that the calculated [Ca] [phytate]/[Zn] molar ratio is a better index for predicting $\mathrm{Zn}$ bioavailability.

\section{Phytate and non phytate $P$}

Table 6 reveals the proportion of phytate and non phytate phosphorus in the mushroom samples in $\mathrm{mg} / 100 \mathrm{~g}$ in dry basis. The proportion of phytate and non phytate phosphorus in the mushroom samples in $\mathrm{mg} / 100 \mathrm{~g}$. Phytate phosphorus ranged from $8.86 \mathrm{mg} / 100 \mathrm{~g}$ (12.4\%) for A.bisporus $\# 2$ to $67.9 \mathrm{mg} / 100 \mathrm{~g}$ (24.2\%) for A.bisporus\#1, while non phytate phosphorus ranged from $61.9 \mathrm{mg} / 100 \mathrm{~g}(87.6 \%)$ for A.bisporus\#2 to $235.5 \mathrm{mg} / 100 \mathrm{~g}$ (88.8\%) for T.clypeatus. Generally diets are regarded as being adequate in bioavailable phosphate. However,

\begin{tabular}{|c|c|c|c|c|c|}
\hline No. & Mushroom Type & Phytate: Zn & Phytate : Fe & Phytate : Ca & Phytate*Ca: Zn \\
\hline 1 & P.ostreatus & $2.47 \pm 0.15$ & $1.82 \pm 0.12$ & $0.08 \pm 0.01$ & $0.071 \pm 0.00$ \\
\hline 2 & L.edodes & $1.27 \pm 0.02$ & $0.90 \pm 0.03$ & $0.03 \pm 0.00$ & $0.066 \pm 0.00$ \\
\hline 3 & A.bisporus\#1 & $2.93 \pm 0.37$ & $3.26 \pm 0.43$ & $0.07 \pm 0.00$ & $0.169 \pm 0.04$ \\
\hline 4 & A. bisporus\#2 & $1.16 \pm 0.09$ & $0.81 \pm 0.08$ & $0.01 \pm 0.00$ & $0.049 \pm 0.00$ \\
\hline 5 & A.campestris & $2.65 \pm 0.30$ & $0.12 \pm 0.01$ & $0.16 \pm 0.2$ & $0.060 \pm 0.00$ \\
\hline 6 & L.sulphureus & $3.76 \pm 0.19$ & $0.75 \pm 0.07$ & $0.11 \pm 0.01$ & $0.075 \pm 0.00$ \\
\hline 7 & T.clypeatus & $1.36 \pm 0.15$ & $0.22 \pm 0.02$ & $0.07 \pm 0.01$ & $0.032 \pm 0.00$ \\
\hline 8 & T.microcarpus\#1 & $1.92 \pm 0.15$ & $0.02 \pm 0.03$ & $0.09 \pm 0.02$ & $0.039 \pm 0.00$ \\
\hline 9 & T.aurantiacus & $N^{*}$ & NA & NA & NA \\
\hline 10 & T. microcarpus \#2 & $2.19 \pm 0.39$ & $0.05 \pm 0.01$ & $0.13 \pm 0.03$ & $0.048 \pm 0.00$ \\
\hline 11 & T.letestui & $1.29 \pm 0.01$ & $0.07 \pm 0.00$ & $0.11 \pm 0.01$ & $0.018 \pm 0.00$ \\
\hline 12 & T. $s p$ & $0.93 \pm 0.02$ & $0.01 \pm 0.00$ & $0.14 \pm 0.00$ & $0.053 \pm 0.00$ \\
\hline
\end{tabular}

*NA=not analyzed 
Citation: Woldegiorgis AZ, Abate D, Haki GD, Ziegler GR (2015) Major, Minor and Toxic Minerals and Anti-Nutrients Composition in Edible Mushrooms Collected from Ethiopia. J Food Process Technol 6: 430. doi:10.4172/2157-7110.1000430

\begin{tabular}{|r|l|c|c|c|c|c|}
\hline \multirow{2}{*}{ No. } & \multirow{2}{*}{ Mushroom Type } & \multicolumn{2}{|c|}{ Total P } & \multicolumn{2}{|c|}{ Phytate P a } & \multicolumn{2}{c|}{ Non phytate P b } \\
\cline { 3 - 7 } & $\mathbf{m g / 1 0 0 ~ g}$ & $\mathbf{m g} / \mathbf{1 0 0} \mathbf{g}$ & $\mathbf{\%}$ & $\mathbf{m g} / \mathbf{1 0 0} \mathbf{g}$ & $\mathbf{\%}$ \\
\hline 1 & P. ostreatus & $250.0 \pm 3.33$ & $43.6 \pm 3.38$ & 17.4 & $206 \pm 3.10$ & 82.6 \\
\hline 2 & L. edodes & $116.5 \pm 1.75$ & $29.2 \pm 0.57$ & 25.1 & $87.2 \pm 1.55$ & 74.9 \\
\hline 3 & A. bisporus \#1 & $282.8 \pm 3.33$ & $67.9 \pm 8.88$ & 24.2 & $213.8 \pm 11.7$ & 75.8 \\
\hline 4 & A. bisporus \#2 & $70.7 \pm 3.45$ & $8.86 \pm 0.97$ & 12.4 & $61.9 \pm 2.80$ & 87.6 \\
\hline 5 & A. campestris & $214.0 \pm 11.3$ & $65.9 \pm 7.10$ & 31.0 & $148.1 \pm 13.8$ & 69.0 \\
\hline 6 & L. sulphureus & $134.6 \pm 3.56$ & $41.3 \pm 0.93$ & 30.8 & $93.3 \pm 4.27$ & 69.2 \\
\hline 7 & T. clypeatus & $265.3 \pm 2.92$ & $29.8 \pm 3.50$ & 11.2 & $235.5 \pm 3.05$ & 88.8 \\
\hline 8 & T. microcarpus \#1 & $215.5 \pm 20.9$ & $33.5 \pm 2.50$ & 16.1 & $182.9 \pm 23.4$ & 83.9 \\
\hline 9 & T. aurantiacus & $135.9 \pm 0.07$ & $\mathrm{NA}$ & & $\mathrm{NA}$ & \\
\hline 10 & T. microcarpus \#2 & $198.4 \pm 10.9$ & $52.3 \pm 8.09$ & 26.6 & $146.0 \pm 14.7$ & 73.4 \\
\hline 11 & T. letestui & $208.5 \pm 6.08$ & $27.5 \pm 0.69$ & 13.2 & $180.9 \pm 5.71$ & 86.8 \\
\hline 12 & T. sp & $235.8 \pm 4.52$ & $19.6 \pm 0.37$ & 8.3 & $216.2 \pm 4.16$ & 91.7 \\
\hline
\end{tabular}

*NA=not analyzed

a=phytate phosphorous calculated by assuming phytate contains $28.18 \%$ phosphorus (phytate * 0.28 )

$\mathrm{b}=$ non phytate phosphorous $=$ total phosphorous - phytate phosphorous

Table 6: Concentration of phytate $\mathrm{P}$ and non phytate $\mathrm{P}$ cultivated and wild edible mushrooms collected from Ethiopia in dry basis.

the high proportion of phosphate as phytate has consequences for bioavailability of minerals and trace elements [64]. In the edible mushrooms evaluated the proportion of phosphate as phytate is low, hence phosphorus from these mushrooms could be bioavailable for the human body (Table 6).

\section{Conclusions}

This study has shown that the mushrooms collected from Ethiopia have good mineral concentrations with lower anti-nutritional factors that make them bioavailable to the human body. However, consumption of some contaminated mushroom should be avoided as they may pose a health risk for consumers. Thus, the outcomes obtained from the study clearly shows there is a great health and nutritional benefits from the consumption of edible mushrooms.

\section{Acknowledgment}

Authors would like to acknowledge Addis Ababa University and Pennsylvanian State University for covering the research costs. Ashagrie is grateful to the finical support he has received from DAAD Germany through the in-country scholarship program.

\section{References}

1. Kalac P, Burda J, Staskova I (1991) Concentrations of lead, cadmium, mercury and copper in mushrooms in the vicinity of a lead smelter. The Science of Total Environment 105: 109-119.

2. Kalac $P$, Svoboda $L$ (2000) A review of trace element concentrations in edible mushrooms. Food Chemistry 69: 273-281.

3. Hobbs C, Beinfield H (1995) Medicinal mushrooms: an exploration of tradition, healing and culture. Botanica Press. Summertown, Tennessee.

4. Kadiri M (1990) The Physiological studies of some Nigerian mushroom. University of Ibadan, Nigeria.

5. Paul I, Turner RE, Ross D (2004) Nutrition. Jones and Barlett Publishers,USA.

6. Ferguson EL, Gibson R S, Lilian UT, Ounpus S, Berry M (1988) Phytate, zinc and calcium contents of 30 East Africa foods and their calculated phytate: $\mathrm{Zn}$, $\mathrm{Ca}$ : phytate and [Ca][phytate]/[Zn] molar ratios. Journal of Food Composition and Analysis 1: 316-325.

7. Lopez WH, Leenhardt F, Coudray C, Remesy C (2002) Minerals and phytic acid interaction: is it a real problem for human nutrition. International Journal of Food Science and Technology 37: 727-739.

8. Schofield P, Mbugua DM, Pell AN (2001) Analysis of condensed tannins: a review. Animal Feed Science and Technology 9: 21-40.
9. Hagerman AE (1998) Tannin Analysis.

10. Harborne J (1998) Phytochemical Methods: A Guide to Modern Techiques of Plant Analysis. Chapman \& Hall, London.

11. Naczk M, Oickle D, Pink D, Shahidi F (1996) Protein precipitating capacity of crude canola tannins: effect of $\mathrm{pH}$, tannin and protein concentrations. Journal of Agricultural and Food Chemistry 44: 2144-2148.

12. Foo LY, Lu Y, McNabb WC, Waghorn GC, Ulyatt MJ (1997) Proanthocyanidins from Lotus pedunculatus. Phytochemistry 45: 1689-1696.

13. Acker VS, Balen PVG, van den Berg DJ, Bast A, Van der Vijgh WJF (1998) Influence of iron chelation on the antioxidant activity of flavonoids. Biochemical Pharmacology 56: 935-943.

14. Mueller-Harvey I, McAllan AB (1992) Tannins: thier biochemistry and nutritional properties. Advanced Plant Cell Biochemistry and Biotechnology 1: 151-217.

15. Morris ER, Ellis R (1989) Usefulness of the dietary phytic acid/zinc molar ratio as an index of zinc bioavailability to rats and humans. Biological Trace Elements Research 19: 107-117.

16. Morris ER, Ellis R (1985) Nutritional Bioavailability of Calcium Washington D.C, USA.

17. Hallberg L, Brune M, Rossander L (1989) Iron absorption in man: ascorbic acid and dose-dependent inhibition by phytate. The American Journal of Clinical Nutrition 49: 140-144.

18. Sandberg AS, Anderson H, Carlesson NG (1987) Degradation products of bran phytate formed during digestion in the human small intestine: effects of extrusion cooking on digestibility. Journal of Nutrition 117: 2061-2065

19. Turnlund JR, King JC, Keyes WR, Gong B, Michel MC (1984) A stable isotope study of zinc absorption in young men: effects of phytate and $\alpha$-cellulose. American Clinical Nutrition 40: 1071-1077.

20. Davies NT, Warrington S (1986) The phytic acid mineral, trace element, protein and moisture content of UK Asian immigrant foods. Human Nutrition and Applied Nutrition 40: 49-59.

21. Ellis R, Kelsay JL, Reynolds RD, Morris ER, Moser PB, et al. (1987) Phytate:zinc and phytate $x$ calcium: zinc milli-molar ratios in self-selected diets of Americans, Asian Indians and Nepalese. Journal of the American Dietary Association 87: 1043-1047.

22. Kalac $P$ (2009) Chemical composition and nutritional value of European species of wild growing mushrooms: A review. Food Chemistry 113: 9-16.

23. Aletor VA (1995) Compositional studies on edible tropical species of mushrooms. Food Chemistry 54: 265-268.

24. Ola FL, Oboh G (2001) Nutrient distribution and zinc bioavailability. Estimation in some tropical edible mushrooms. Nahrung/Food 45: 67-68.

25. Akindahunsi AA, Oyetayo FL (2006) Nutrient and antinutrient distribution of edible mushroom, Pleurotus tuber-regium (fries) singer. LWT-Food Science and Technology 39: 548-553

26. Atlabachew M, Chandaravanshi BS (2008) Levels of major, minor and trace elements in commerically available enset (Enset ventricosum (Welw.), Cheesman) food products (Kocho and Bulla) in Ethiopia. Journal of Food Composition and Analysis 21: 545-552.

27. Chen XH, Zhou HB, Qiu GZ (2009) Analysis of several heavy metals in wild edible mushrooms from regions of China. Bull Enviromental Contamination and Toxicology 83: 280-285.

28. Isildak O, Turkekul I, Elmastas M, Tuzen M (2004) Analysis of heavy metals in some wild-grown edible mushrooms from the middle black sea region, Turkey. Food Chemisty 86: 547-552.

29. AOAC (1990) Official methods of analysis. Washington DC,USA.

30. Latta M, Eskin MA (1980) A simple and rapid colorimetric determination of phytate. Journal of Agriculture and Food Chemistry 28: 1313-1315.

31. Vaintraub IA, Lapteva NA (1988) Colorimetric determination of phytate in unpurified extracts of seeds and the products of their processing. Analytical Biochemistry 175: 227-230

32. Burns RE (1971) Method of estimation of tannin in grain sorghum. Agronomy Journal 63: 511-512. 
Citation: Woldegiorgis AZ, Abate D, Haki GD, Ziegler GR (2015) Major, Minor and Toxic Minerals and Anti-Nutrients Composition in Edible Mushrooms Collected from Ethiopia. J Food Process Technol 6: 430. doi:10.4172/2157-7110.1000430

33. Maxon ED, Rooney LW (1972) Evaluation of method for tannin analysis in sorghum grain. Cereal Chemistry 49: 719-729.

34. Norhaizan ME, Nor Faizadatul Ain AW (2009) Determination of phytate, iron zinc, calcium contents and their molar ratios in commonly consumed raw and prepared Food in Malaysia. Mal J Nutr 15: 213-222.

35. Genccelep H, Uzun Y, Tunçtürk Y, Demirel K (2009) Determination of mineral contents of wild-grown edible mushrooms. Food Chemistry 113: 1033-1036.

36. Vetter J (1993) Chemical composition of eight edible mushrooms. Zeitschrift für Lebensmittel Untersuchung und Forschung 196: 224-227.

37. Mattila P, Könkö K, Eurola M, Pihlava J, Astola J, et al. (2001) Contents of vitamins, mineral elements and some phenolic compounds in cultivated mushrooms. Journal of Agricultural and Food Chemistry 49: 2343-2348.

38. Ouzouni PK, Veltsistas PG, Paleologos EK, Riganakos KA (2007) Determination of metal content in wild edible mushroom species from regions of Greece. Journal of Food Composition and Analysis 20: 480-486.

39. Mendil D, Uluozlu OD, Hasdemir E, Caglar A (2004) Determination of trace elements on some wild edible mushroom samples from Kastamonu, Turkey. Food Chemistry 88: 281-285.

40. Rudawska M, Leski T (2005) Macro and microelement contents in fruiting bodies of wild mushrooms from the Notecka forest in west-central Poland. Food Chemistry 92: 499-506.

41. Sesli E, Tüzen M (1999) Levels of trace elements in the fruiting bodies of macrofungi growing in the East Black Sea region of Turkey. Food Chemistry 65: 453-460.

42. Turkekul I, Elmastas M, Tuzen M (2004) Determination of iron, copper manganese, zinc, lead, and cadmium in mushroom samples from Tokat, Turkey. Food Chemistry 84: 389-392.

43. Işiloğlu M, Yilmaz F, Merdivan M (2001) Concentrations of trace elements in wild edible mushrooms. Food Chemistry 73: 169-175

44. Soylak M, Saracoglu, Tüzen M, Mendil M (2005) Determination of trace metals in mushroom samples from Kayseri, Turkey. Food Chemistry 92: 649-652.

45. Tüzen M, Ozdemir M, Demirbas A (1998) Study of heavy metals in some cultivated and uncultivated mushrooms of Turkish origin. Food Chemistry 63: 247-251.

46. European Commission (2003) Opinion of the Scientific Committee on Food on the Tolerable Upper Intake Level of Copper. Brussels, Belgium.

47. Tüzen M (2003) Determination of heavy metals in soil, mushroom and plant samples by atomic absorption spectrometry. Microchemical Journal 74: 289-297.

48. Kawai H, Sugahara T, Fujishiro S, Matsuzawa M, Aoyagi Y, et al. (1990) Mineral contents in edible mushrooms growing on woods-Comparison with mineral contents in mushrooms growing in soil. Nippon Shokuhin Kogyo Gakkaishi 37: 468-473.

49. Breene WM (1977) Nutritional and Medicinal Value of Specialty Mushrooms Journal of Food Protection 53: 883-894.

50. Garcìa MA, Alonso J, Fernandez MI, Mel ga MJ (1998) Lead content in edible wild mushrooms in Northwest Spain as indicator of environmental contamination. Archives of Enviromental and Contamination Toxicology 34: 330-335.

51. Kalac P, Wittingerova M, Staskova I, Simak M, Bastl J (1989) Contents of mercury, lead and cadmium in mushrooms. Cesk Hyg 34: 568-576.

52. FAO/WHO (1989) Evaluation of certain food additives and contaminants Report of the Joint FAO/WHO. WHO Technical Report Series.

53. Council of Europe (2001) Policy statement concerning metals and alloys Guidelines on metals and alloys used as food contact material. Brussels: Council of Europe.

54. Akindahunsi AA, Oboh G (1999) The Abdus-Salam Int. Centre for Theoretical Physics Preprint IC/99/25.

55. Sandberg AS, Anderine R (1986) HPLC method for determination of inositol tri, tetra-, penta- and hexaphosphates in food and intestinal contents. Journal of Food Science 51: 547-50.

56. Han O, Mark LF, Hill D (1994) Inositol phosphates inhibit uptake and transport of iron and zinc by a human intestinal cell line. Journal of Nutrition 124: 580-587.

57. Lonnerdahl B, Kunz C, Sandberg AS (1987) Inhibitor effects of various inosito phosphates on zinc and calcium absorption. Federation Proceedings 46: 599.

58. Laurena AC, Truong VD, Mendoza EMT (1984) Effects of condensed tannins on in vitro digestibility of cowpea [Vigna unguiculata (L.) Walp]. Journal of Agricultural and Food Chemistry 32: 1045-1048.

59. Osagie AU (1996) Nutritive quality of plant foods. Nigeria: Benin city: PostHarvest Research unit of the University of Benin.

60. Oberleas, Donald (1983) Phytate content in cereals and legumes and methods of determination. Cereal Food World 28: 352-357.

61. Davies NT, Olpin SE (1979) Studies on the phytate: zinc molar content in die as a determinant of $\mathrm{Zn}$ availability to young rats. British Journal of Nutrition 41: 591-603.

62. Oberleas D, Harland BF (1981) Phytate contents of food: Effect on dietary zinc bioavilability. Journal of the American Dietetic Association 79: 433-436.

63. Hurell RF (2004) Phytic acid degradation as a means of improving iron absorption. International Journal for Vitamin and Nutrition Research 74: 445-452.

64. Umeta M, West CE, Fufa H (2005) Content of zinc, iron, calcium and their absorption inhibitors in foods commonly consumed in Ethiopia. Journal of Food Composition and Analysis 18: 803-817. 